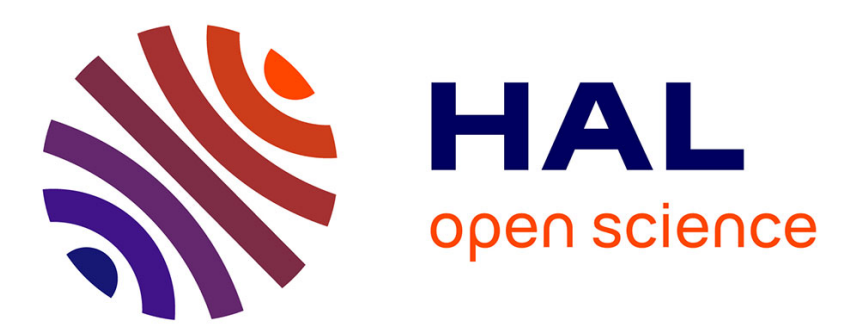

\title{
Assessing the cost, effectiveness and acceptability of best management farming practices: a pluridisciplinary approach
}

Nadine N. Turpin, Ramon Laplana, Peter Strauss, Minna Kaljonen, Frédéric Zham, Véronique Bégué

\section{To cite this version:}

Nadine N. Turpin, Ramon Laplana, Peter Strauss, Minna Kaljonen, Frédéric Zham, et al.. Assessing the cost, effectiveness and acceptability of best management farming practices: a pluridisciplinary approach. 2005. hal-02829407

\section{HAL Id: hal-02829407 https://hal.inrae.fr/hal-02829407}

Preprint submitted on 7 Jun 2020

HAL is a multi-disciplinary open access archive for the deposit and dissemination of scientific research documents, whether they are published or not. The documents may come from teaching and research institutions in France or abroad, or from public or private research centers.
L'archive ouverte pluridisciplinaire HAL, est destinée au dépôt et à la diffusion de documents scientifiques de niveau recherche, publiés ou non, émanant des établissements d'enseignement et de recherche français ou étrangers, des laboratoires publics ou privés. 


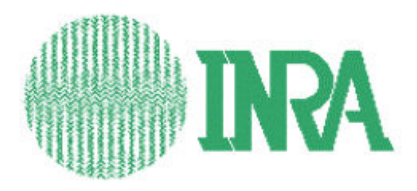

Institut National de la recherche Agronomique

Unité d'Economie et Sociologie Rurales

4 Allée Adolphe Bobierre, CS 61103

F 35011 Rennes Cedex

Tél. (33) 02234853 82/53 88 - Fax (33) 0223485380

http://www.rennes.inra.fr/economie/index.htm

\section{Assessing the cost, effectiveness and acceptability of best management farming practices : \\ a pluridisciplinary approach}

Nadine Turpin, Ramon Laplana, Peter Strauss,

Minna Kaljonen, Frédéric Zahm, Véronique Bégué

Juillet 2005

Working paper 05-02 


\section{Assessing the cost, effectiveness and acceptability of best management farming practices :a pluridisciplinary approach}

Nadine Turpin, Ramon Laplana, Peter Strauss,

Minna Kaljonen, Frédéric Zahm, Véronique Bégué

Cemagref Clermont et INRA-ESR Rennes

Cemagref Bordeaux

Bundesamt für Wasserwirtschaft, Petzenkirchen Austria

Finnish Environmental Institute, Helsinki Finland

Chambre d'agriculture de Loire Atlantique

Adresse pour correspondance

INRA

4, allée Adolphe Bobierre

CS 61103

35011 Rennes cedex, France

e-mail : nadine.turpin@rennes.inra.fr

\section{Remerciements}

Nous sommes reconnaissants du soutien financier de l'Union Européenne à travers le projet AgriBMPWater (EVK1-CT-1999-00025) 


\title{
Assessing the cost, effectiveness and acceptability of best management farming practices :a pluridisciplinary approach
}

\begin{abstract}
The AgriBMPWater project has been imagined and built in a pluridisciplinary approach and framework, with the study of the object "BMPs" by several disciplines at the same time (hydrology, economy, sociology, geography and agronomy). The knowledge of the object in each discipline is deepened by a fertile multi-field contribution: disciplines borders have been broken down, allowing crossbreeding between different scientific fields. This crossbreeding becomes necessary as sustainability in agriculture and livestock production gathers together very different and evolving notions. Moreover, crossbreeding between scientific findings and on-farm application contributed to enrich the analysis.
\end{abstract}

Keywords : cost-effectiveness, Non Point Source pollution, acceptability, Best Management Practice

\section{Résumé}

Le projet AgriBMPWater a été construit autour d'une approche pluridisciplinaire pour étudier l'objet "bonne pratique agricole" simultanément par plusieurs disciplines (hydrologie, économie, sociologie, géographie et agronomie). L'approche de cet objet par chacune des disciplines est approfondi par une contribution des autres champs. Le croisement des concepts des différentes disciplines permet d'enrichir l'analyse, et de proposer des mesures de régulation des pollutions diffuses plus efficaces.

\section{Mots clefs :}

analyse coût-efficacité, pollution diffuse, acceptabilité, bonnes pratiques agricoles 


\section{Assessing the cost, effectiveness and acceptability of best management farming practices :a pluridisciplinary approach}

\section{Introduction}

This paper focuses on alternative practices that are proposed to farmers on a voluntary basis to improve the water quality in rural watersheds. These alternative practices are known as "best management practices" in the USA (US Clean Water Act, amended 2002), "agrienvironemental measures" in Europe (EU Council Regulation №2078/92/EEC) or "Nitrate Sensitive Areas Scheme" in the United Kingdom. The European Council considered during the Gothenburg meeting (June 2001) that more than $20 \%$ of the utilized agricultural area is farmed under agri-environment contracts. But the first environmental assessments of these contracts conclude that they have only little impact, for two main reasons: they have a low adoption rate, and farmers participation do not coincide with the areas of highest environmental value or need (European Environment Agency 2003).

The environmental policy concerning water preservation is well established, with the EU Water Framework Directive (WFD) in place. Focus now needs to be put on procedures for implementation (Commission of the European Communities 2005). The WFD mandates the adoption of restoration plans by water sectors. As a consequence, local managers have to design these plans. Nevertheless there are hundreds of environmentally friendly practices for each Member State. The local managers need to select among them the most cost-effective ones and those which are liable to be the easiest to adapt for the farmers. Designing agrienvironmental schemes without considering together the three dimensions - cost, effectiveness, acceptability - may result in measures which are efficient but extremely expensive (Deffontaines et al. 1993), cheap but with low environmental performances (OECD 2003), or even worse, the instrument may be cost-effective but experience very low commitment (Harvey 2004). In any cases, even if the selected environmentally friendly practices improve the sustainability of the farms who adopt them (Webster 1999), there may be no improvement at the watershed or regional scale when the commitment is too low (Prato, 1999).

In this context, the aim of the AgriBMPWater research project was to help decision makers in selecting among existing BMPs the most cost-effective ones and those which may be more 
easily adopted by the farmers (Turpin et al. 2005). The general framework developed during the project takes into consideration:

- a cost/effectiveness approach to assess BMPs relevance to environmental and economic objectives;

- an acceptability approach to estimate the potentiality of farmers joining BMPs;

- an evaluation of the implementation practices, that should be initiated to ensure a better information of farmers.

The AgriBMPWater project was built on a pluridisciplinary approach and framework, with the study of the object "BMPs" by several disciplines (agronomy, hydrology, economy, sociology). The knowledge of the object in each discipline is deepened by a fertile multi-field contribution: disciplines borders have been broken down, allowing crossbreeding between different scientific fields. This crossbreeding becomes necessary as sustainability in agriculture and livestock production gathers together very different and evolving notions, like resource efficiency, profitability, productivity, environmental soundness and social viability (Gamborg and Sandoe 2005).

This paper describes two elements : on the one hand, the way the cooperation between the different disciplines can improve the comparison of different BMPs is analysed in Section 2 and its application on a case study described in Section 3. On the other hand, the aim of the AgriBMPWater project was to support decision makers selecting BMPs. Thus, we also focused on the implementation of the research results: Section 4 presents how these research results can be translated into farmers advice. Last, Section 5 highlights the key points that may improve the design of agri-environmental schemes.

\section{Crossbreeding between scientific fields}

\section{A common study object : the Best Management Practice}

The literature dealing with environmentally friendly farming practices is large in each of the disciplines involved in the analysis. Hydrology focuses on the design, location or combination of these BMPs to comply with water standards (Anderson and Flaig, 1995). In most models, a BMP is represented as a change in some coefficient describing a conventional farming practice. Economists focus on the economic instruments that could improve BMPs adoption (not on the BMPs themselves), and more recently on the econometric assessment of the 
relationship between BMPs adoption and farm profitability (Valentin et al., 2004). Sociological studies on BMPs adoption are a fertile area, especially in the micro-sociological studies of participation (Morris and Potter, 1995, Ward and Munton, 1993, Wilson and Hart, 2000).

None of these discipline focus on the design of BMPs themselves, but rather on their consequences from a specific point of view. Thus, and because we aimed at implementing some of the BMPs analysed through the whole framework, we started with BMPs designed by agronomists, or landscape managers, who consider their feasibility in terms of farming techniques and agricultural systems management.

In the European Union, the contractual and volunteer agri-environmental measures rely mainly on agronomic recommendations and landscape management. For example, french farmers have been proposed 2,650 different measures (Instance Nationale d'Evaluation du Contrat Territorial d'Exploitation, 2003), that have been validated by national and European processes. We wanted to broaden the definition of the study object to include any practice that could be designed by scientists on the basis of scientific results, or extension services on the basis of experience.

The integrated models which consider the cost and effectiveness sides of BMPs adoption and the variability of the farms are still scarce and integrated environment assessment is still a developing discipline (Pierce 1998). For this reason, the framework proposes to integrate existing models rather than developing new ones. This framework iterates six main steps :

- the BMPs are introduced into hydrologic models (step 1) as land use practices,

- these models provide both BMP efficiency (step 2), and BMPs combination scenarios,

- the BMPs scenarios are introduced into economic models (step 3),

- the economic models provide costs for the first set of scenarios (step 4),

- because the BMPs are proposed on a voluntary basis, crossbreeding between hydrology and economics designs critical areas (step 5)

- if the sociological study (step 6) suggests that the BMPs are liable to be accepted on the critical areas and step 5 estimates that they may lead to comply with water quality standards at reasonable cost, the study stops.

- if not, new BMPs scenarios are designed, from the economic or sociologic results and introduced into hydrological models, and so on.

The results of this iterative framework are presented as a grid which depicts on each watershed the contracted area, the effectiveness of the BMP, the associated costs and either the current participating area or the potential area where the BMP is acceptable. 


\section{Effectiveness assessment}

The environmental effectiveness of a given BMP is defined within the AgriBMPWater project as the evolution of water quality led from the BMP implementation on a watershed or on some specific areas within this watershed.

Basically, implementing a BMP on a given area will have short term and long term consequences on water quality, while modifying specific discharge, pollutant pathways, nutrient cycles and so on. The effectiveness should be considered as the difference between the baseline scenario and the modified scenario, each system being in equilibrium.

Uncertainty analysis provide the possible uncertainty existing in the estimation of effectiveness. We neglected in our analysis the effects of climate variability that can be important for short term estimations (Lacroix et al., 2005): we estimated only long term trends on water quality.

Effectiveness is estimated through the introduction of pre-designed BMPs as alternative practices in previously validated models. Each BMP effectiveness can be determined as the ratio between the initial state and the estimated state after BMP implementation, both systems being in equilibrium (Holmes, 1996). Effectiveness is calculated as:

$$
\text { effectiveness }=\frac{V A R_{B M P}-V A R_{r e f}}{V A R_{r e f}} \times 100
$$

where $V_{A R} R_{B M P}$ is any variable simulated with a specific BMP implemented and VARref is measured or simulated with the ordinary practice in the baseline scenario (Laplana et al. 2004). The assessment takes place at the outlet of the watershed.

\section{Costs}

The Water Framework Directive integrates economics into water management and water policy decision making. We shall restrict the economic approach to the assessment of the costs associated with the implementation of BMPs, even though the WFD requests a wider economic analysis. 
We consider an economy which includes consumers (of agricultural products), tax-payers and producers, split into farmers and other producers ${ }^{1}$. Farmers suffer a profit loss when adopting BMPs which are less profitable than conventional practices. We modelled only medium term profit losses, that is we assumed that production means such as land or machinery are fixed (labour can be hired from outside the farm). The BMPs are proposed to the farmers on a voluntary basis : the regulator must compensate the farmers for their profit loss if she wants them to participate. On the one side, this compensation increases the participating farmers' profit, but on the other side it has a cost for the society : either the money is not yet available for other policies, or there is a need to rise the taxes paid by the tax-payers.

The total variation of farmers' profit (considering both losses from the BMP adoption and the gain from the compensation) is included into the "direct costs" of the BMP implementation.

The surplus variation borne by the other components of the economy but the agricultural sector are named "indirect costs". There are several reasons why such indirect costs are likely to appear. When the farmers try to compensate for direct costs induced by BMPs implementation, then can raise their output prices so that agricultural goods would be more expensive for intermediate and final consumers or, if they cannot do so, they can switch to more profitable products, which has an impact on transformation industries and final consumers.

Depending on the size of the watershed and on the candidate BMP, consumers, tax-payers, regulated producers and producers belonging to other sectors of the economy may be affected or not and therefore the expression of the surplus variation may be simplified.

Obviously, implementing BMPs on very large watersheds or nationwide leads to a surplus variation for all the components of the economy (consumers, agricultural producers, taxpayers and other sectors of the economy). For smaller watersheds, with a size close to a river basin district, the production variation induced by the environmental policy is small enough to have no effect on the price, and the consumers' surplus variation can be neglected when assessing the direct costs associated with this policy.

\footnotetext{
${ }^{1}$ We neglected transaction and administrative costs, though they are of importance on the choice of mitigating instruments (Kampas and White, 2004).
} 
When implementing BMPs on a small watershed (less than $100 \mathrm{~km}^{2}$ ), the indirect effects on the other sectors of the economy can be neglected. If the BMP is associated with a subsidy that compensates the producers' profit losses, then the cost of the BMP is related to the taxpayers' profit variation only.

The choice of an economic model is strongly related to the surplus variations that have to be estimated.

When all the components of the economy can be affected by the BMP, only a computable general equilibrium model can estimate the associated costs (Dellink, and van lerland, 2005).

On large river basin districts, computable general equilibrium models are still relevant when the BMP may affect largely the non-agricultural sector of the economy, but other types of models are also available. When the variability of the farms is large, this parameter can be included in the modelling while using a Principal-Agent model: the farmers are represented as a continuum characterized by a one-dimensional parameter representing their private information ( $\mathrm{Wu}$ and Babcock, 1996). This kind of model allows the design of optimally differentiated policies while providing a menu of contracts adapted to each kind of farm and the associated variation of producers' plus tax-payers' surplus variation.

When only the tax-payers' surplus variation has to be estimated, linear programming models can be used (see Vatn, 1999, for an example). Note that these models are easier than the others to connect with hydrological models when they explicitly represent on-field agricultural practices, but they usually present aggregation problems at the watershed scale.

\section{Acceptability}

Agri-environmental schemes are based on individual farm-level contracts, which are often voluntary in nature. However, in order to diminish diffuse pollution, a BMP applied in one individual farm is not necessarily enough. In fact, BMPs should be targeted on critical areas and to a group of farms. This requires actions from a number of actors and institutions and at the same time raises collective action problems.

The problem of low implementation rates of BMPs is still too often only explained by the resistance of farmers (Ruttan, 1996). However, experience has shown that problems also occur in the various phases of the policy implementation and in the dissemination of information. 
In order to increase our understanding of the social factors that contribute to the acceptability of the BMPs and agri-environmental policy, more attention has to be paid to the implementation practices at the local and farm level. This means giving due consideration to the role of farmers in the agri-environmental management and policy implementation practices. The evaluation of the institutional setting is of uttermost importance, when the social acceptability of the BMPs and agri-environmental policy is assessed.

The study of the social acceptability can vary from a survey of willingness to contract to an extensive study of the implementation practices. In the AgriBMPWater project our studies on social acceptability were based on the following methods:

- Several simplified case studies, which determined the social factors affecting the "willingness to contract", main barriers in contracting, legitimacy of the agri-environmental policy and farmers attitudes towards environmental issues in general. The empirical material was gathered with surveys and focus group studies. The surveys focused on the following issues:

- changes in the environmental management practices,

- acceptability of the agri-environmental policy model and its future development

- information channels,

- specific questions on BMP contracts (impact on farm management and environment, the level of compensation),

- local environmental problems and actions.

- One extensive case study, which examined the implementation practices of the agrienvironmental policy at the local and farm level. The study was focused on the analysis of the practices of different actors and interplay between the agri-environmental implementation and farming practices. Special attention was put on the dynamics of translating policy goals into farming practices and arising intermediary mechanisms. The empirical material was gathered with thematic interviews, observation and surveys.

\section{Critical areas delineation}

The Water Framework Directive requests the identification of Heavily Modified Water Bodies, where more emphasis should be put on restoration measures. The concept of critical areas developed here is different. Even for slightly modified water bodies, it is obvious that all the components of the watershed do not contribute at the same level to the Non Point Source 
(NPS) pollution process. Besides, the least costly way for the economy (or for specific economic sectors, here the agriculture) to achieve well-defined environmental objectives for water resource often requires to target the measures to specific areas where they may be more effective, or cheaper to implement (Wu and Babcock, 2001).

The delineation of critical area emphasizes the role of crossbreeding between disciplines. The intuition is simple : usually, the BMPs are proposed to the farmers on a voluntary basis, often with a premium to compensate the associated costs. The farmers who have the lower costs of adoption will adopt the BMPs first. As the farmers are not uniformly scattered within a watershed which, in general, is not physically uniform either, the costs and acceptability of the BMPs have consequences on their environmental effectiveness also: for a given watershed, if the farmers located on the more sensitive areas have higher costs of adoption, they will not implement the BMP unless the associated premium is very high, and the BMP effectiveness on this watershed may drop dramatically.

When the watershed can be split into smaller homogenous areas, a two-stages allocation of agri-environmental funds can be proposed : the first stage consists in delineating eligible sites and the second stage in allocating the funds in these sites on a criterion of environmental effectiveness (Wu 2004). Within AgriBMPWater, we defined "critical areas" to meet this target.

At this stage of the analysis, it is really important that physicists, economists, sociologists and stakeholders agree on a common definition for these priority zones, named "critical areas". This definition will strongly depend on the aim of the study. Please refer to Turpin et al. (2005) for all the definitions below. If only physicists are involved in the river basin management plan, the study will have a natural science theoretical aim and a critical area can be defined as "the minimum area, where feasible measures can be applied, needed to reach the desired quality standard of the considered pollutant at the receptor (outlet or pumping station)". When many stakeholders participate in the diagnosis, an operational aim can be adopted and the critical areas are "the sets of areas where feasible measures can be applied needed to reach the desired quality standard of the considered pollutant at the receptor." More often, physicists, stakeholders and economists are involved in the restoration plan. In this case, critical areas can be defined as "the set of areas where feasible measures can be applied to reach the desired quality standard of the considered pollutant at the receptor at the least social cost" (welfare economic aim). 
The use of a spatially distributed hydrologic model is of importance to select, among all the watershed areas, some of them where the implementation of BMPs is expected to be more efficient. These models need to be calibrated first on a baseline scenario. This baseline scenario is usually designed from traditional agricultural practices. In order to separate areas with higher risk from areas with lower risk, there is a need to rank the specific pollutant loads from each unit area with respect to the others. A sensitivity analysis will provide great help at this stage for the interpretation of ranking the different areas according to their potential effect on the BMP effectiveness. Once the different unit areas from watershed are ranked, their specific simulated effectiveness has to be combined, so that each BMP delineates the areas defined as critical according to the natural science definition.

To go further in the delineation of critical areas, the stakeholders and firms interests can be taken into consideration. The areas where potential BMPs are modelled to be most effective may differ from the areas where the same BMPs are more liable to be implemented. Then, the different areas have to be ranked according to both effectiveness and acceptability criteria, before delineating the "critical areas" according to the operational aim.

The same procedure can be applied to design critical areas according to the welfare economic aim, the candidate areas being ranked according to a cost-effectiveness ratio, their potential acceptability being also considered.

Note that the delineation of critical areas according to the two last definitions is an iterative process which is often time consuming. Most studies use the physical definition of critical areas only.

Although linearly presented, the analysis is iterative: initial analysis is based on existing information, and will be upgraded as new information and knowledge are gathered.

\section{A grid to improve comparisons of BMPs}

The integration is performed through a synthetic diagram that depicts on each watershed the contracted area, the effectiveness of the BMP, the associated costs and either the current participating area or the potential area where the BMP is acceptable.

When choosing between BMPs there is a trade-off between costs and environmental effects. Generally, high cost policies are more difficult to implement. If warranted for environmental reasons, i.e., other BMPs fail to reach environmental targets, more care must be taken in 
terms of designing contract menus that ensure that in relative terms, low cost providers of high cost BMPs implement the BMP first. In practical terms this implies designing contract menus such that make it the dominant strategy of agents (farmers) to truthfully reveal their costs of implementing the BMP. If it is difficult to design policies that make low cost providers adopt the BMP, the concept of critical areas is a helpful tool to identify farmers or fields, where adoption of high cost BMPs are the least costly. The rationale for this is that such micro level cost and environmental effectiveness differences may occur even within a watershed or small regions.

\section{Comparison of BMPs on a watershed}

\section{Watershed description}

The Don watershed (71 706 ha) is located in the western part of France, in "Pays de la Loire" region. Farm production is mainly cattle breeding (dairy and meat productions), where cereals are grown for both grain and forage. Indoor breeding is still of low importance, but the number of pig and poultry farms is increasing. Grasslands, associated with dairy production, account for around $50 \%$ of total agricultural area. Cereals represent $18 \%$ and corn $15 \%$ of the total area. The average size of farms was 74 ha in 1999 . The weather is typically oceanic, with cool wet winters and warm drier summers. The Don watershed is covered by brown soils resulting from the alteration of the underlying schist rock. The watershed being quite flat and soil hydraulic conductivities rather low, these thin soils (60 to $90 \mathrm{~cm}$ deep) are frequently hydromorphic. The water coming from the Don watershed is connected to two pumping stations for drinking water, supplying around 150,000 people. The "Departmental Council of Loire Atlantique" monitors water flows and nitrate concentrations at the "Conquereuil" station (draining 59306 ha of the whole Don watershed).

In the Don watershed, the nitrate concentration regularly reached or exceeded the EU guidelines of $50 \mathrm{mg} / \mathrm{l}$ at the "Conquereuil" pumping station in the mid-nineties when a recovery program was elaborated by local extension services. Cropping, fertilising and manuring advice have been proposed to the farmers who could voluntary choose to adopt them or not. For several years, no change in water quality has been noticed, so the attention focused to the rate of adoption of the "best practices" that had been promoted on this watershed. 


\section{Building the comparison grid}

\section{Data collection}

On this watershed, the analysis focussed on the diversity of the farms, of their practices and of the relationship between the supply of commodity outputs and $\mathrm{N}$ emissions. Data describing on-farm practices have been collected on a sample of $10 \%$ of the farms after stratification of the whole population on production system criteria (see Turpin, et al., 2005 for details). During the survey, special attention has been paid to the evolution, during the last five years, of the stages of decision making by the farmers faced with environmental questions. A precise description of the fertilisation practices for each crop in each rotation has been collected for the last ten years. For the farmers who accepted it, gross and net output, production costs have been collected for the last three years.

Working with the farmers and the extension services along the analysis lead to the emerging idea that the reasons why a farmer may adopt BMPs are quite different from one farm to another and often go beyond strict economic considerations. The simplest way to characterise theses reasons was to simply ask the farmers to describe what they changed in their own farms during the survey, and add open questions to allow them to describe why they modified something. From the farmers' answers, the extension services grouped the farms into 8 types according to a multiple correspondence analysis (Leparoux et al. 2001):

- T1 farms are characterised by small production means (land, labour and capital), practices are very stable, all the crops are over-fertilised; the farmers do not consider the environmental consequences of their practices.

- $\quad$ T2 farmers are rather old, they have small dairy quotas but the farm area is larger than T1. The grassland area is rather extensive and the cropland area highly over-fertilised. These farmers consider that they are not concerned by environmental questions, because they have small farms compared to the others in the watershed.

- T3 farm are beef growers. The soils are heavy, wet and cold. The mean concern for these farmers is to reduce production costs and simplify the production system ; they are open to changes and very sensitive to how consumers perceive farming from the beef crisis in France.

- T4 farms are dairy producers with very specific systems: the forage production is built on extensive grassland, the corn area is as small as possible. These farms greatly evolved from the last ten years and improved labour organisation, increase gross margins, consider the environmental consequences of the practices. 
- T5 farms are dairy farms. The farmers look for an increase of their income through an increase of the production outputs. Dairy cows are mostly feed with corn, the area devoted to cereals is large and the grassland area is intensive. These farmers did not entered the farming networks existing on the watershed, and usually do not consider the environmental consequences of what they do.

- $\quad$ T6 farms are also mostly dairy farms, but the farmers try to improve their income through a decrease of their production costs. The forage systems in evolving, with an increase of the grassland area. These farmers are open to the environmental considerations but there is still large room for improvements on these farms.

- $\quad$ T7 farmers are mostly interested into crop growing and they continuously improve their cropping techniques, the material they use.

- T8 farms are associations for which the improvement of the income was more performed through the increase of the product output than a decrease of the costs. The cattle is mostly feed with corn, the herds are large ; the farm trajectory is based on productivity and the farmers are more or less sensitive to the environment.

\section{Step 1 : hydrological modelling}

The $\mathrm{N}$ emissions from the agricultural activity have been estimated with the SWAT model (see Turpin, et al., 2005 for details). The SWAT (Arnold et al., 2001) is a semi-distributed watershed model with a GIS interface (DiLuzio et al., 2002) that outlines the sub-basins and stream networks from a digital elevation model and calculates daily water balances from meteorological, soil and land-use data. SWAT simulates each sub-basin separately according to the soil water budget equation taking into account daily amounts of precipitation, runoff, riverbed transmission losses, percolation from the soil profile, and evapotranspiration. The modelling confirms what has already been observed on other watersheds in the Western part of France: there is not ONE production systems that causes more emissions than the others, but a multitude of practices with a large range of risks (Bontems et al., 2004).

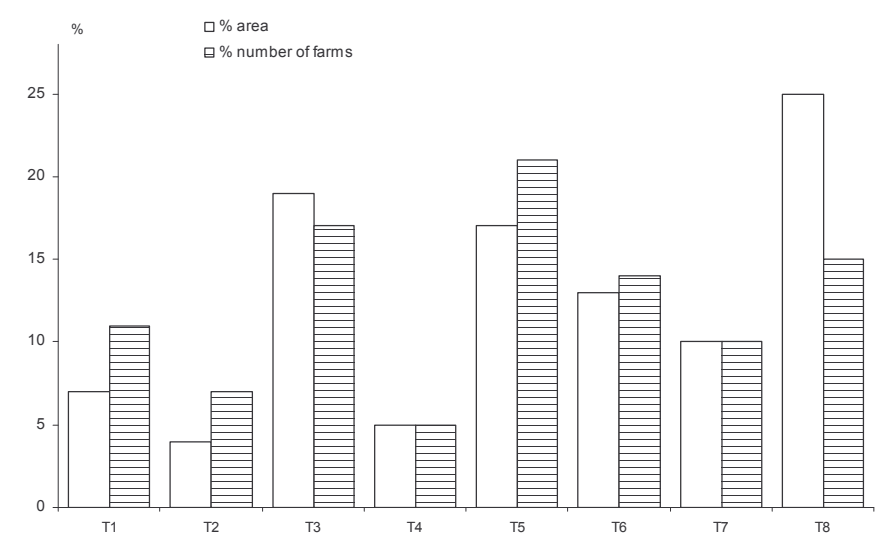


Figure 1: types of farms on the Don watershed, number of farms and cropped area

\section{Step 2 : environmental effectiveness}

The BMPs that have been described to the farmers concern fertilisation (organic and nonorganic). These BMPs are modelled as being able to decrease the $\mathrm{N}$ losses at the outlet of the watershed below the EU threshold of $25 \mathrm{mg} \mathrm{NO} 3 / \mathrm{l}$ when applied widely.

\section{Steps 3 and 4 : economic modelling and cost assessment}

The consequences of these BMPs for the farmers may affect their income with possible yield losses, an increase of labour and machinery requirements (to spread the manure on fields far from the stable), costs for learning the new techniques. Bontems et al. (2005) reduced the heterogeneity of the farms along two dimensions, their ability to transform inputs into final production and the available area they possess. Productive ability is private information to the farmers while available area and final production are observable characteristics. This analysis was the basis for the assessment of the cost-effectiveness ratio for the modelled BMPs, like decrease of mineral fertilisers (BMP1), better use of manure (BMP2) or both (BMP3).

\section{Step 5 : Critical areas}

The Don watershed is physically heterogeneous, with heavy clay soils upstream and light lime soils downstream. The farmers are heterogeneous too, and the relationship between farming practices and $\mathrm{N}$ emission is largely non-linear (Bontems et al., 2004). Thus we adopted the welfare economic aim definition of the critical areas for each BMP.

Let us examine the BMP2 on the Don watershed as an example. This BMP consists in spreading the on-farm manure on the grassland area rather than on corn fields and to disseminate the amount of produced manure on a larger area than previously. This BMP is associated with technical constraints, like delays between manure spreading and grazing periods, modification of the grass growth, and causes additional costs for transporting to fields that are distant from the stable. This BMP improves the water quality while modifying the rate and chronology of fresh organic compounds mineralization along the crop rotations. A regulator willing that the farmers adopt this BMP can rank the different sub-watersheds in the area according to a cost-effectiveness ratio, define critical areas, and encourage the farmers to adopt the BMP on these critical areas first. Unfortunately, the farms who crop 
these areas do bear the higher decrease of emissions per hectare than other farms. As a consequence, their adoption cost, expressed per hectare of implementation, is far greater than for the other farms (see Figure 2). Obviously, these farms would be the last to adopt the BMP if it would have been proposed on the whole watershed: in this case, targeting the measures leads to an important decrease of the total cost of the measure.

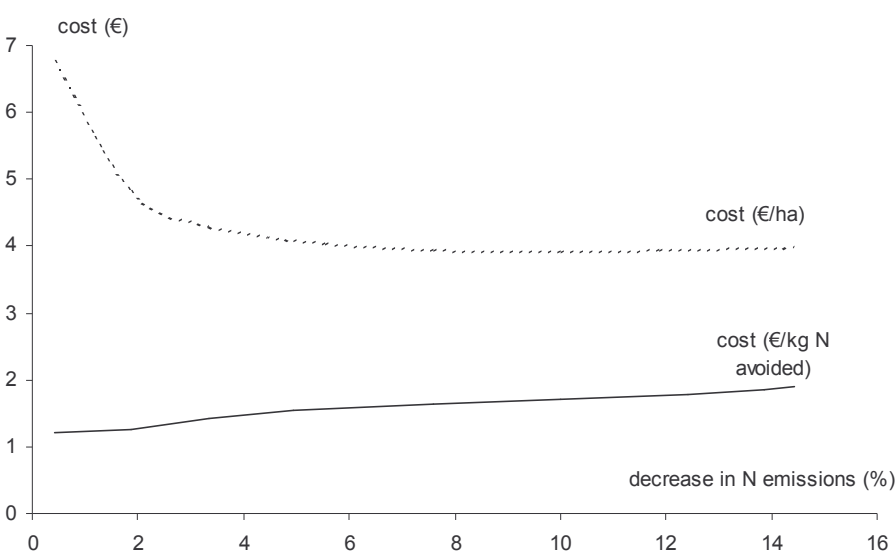

Figure 2: costs associated by the implementation of the BMP2 on the Don watershed - costs perceived by the farmers ( $€ /$ ha implemented) and cost-effectiveness for the regulator $(€ / \mathrm{kg}$ of avoided $\mathrm{N}$ emission).

The definition of the critical areas is of utmost importance for the analysis of the BMPs' consequences : the way the different candidate areas are rank may considerably modify the results of a cost-effectiveness analysis.

Moreover, when several BMPs are proposed to the farmers, the different critical areas for each BMP do not coincide and the cost of implementation for two complementary BMPs are often quite different of the sum of the unit costs. Let us illustrate this fact with the BMP3 on the Don watershed, which technically is BMP1 plus BMP2. The critical areas for BMP1 and BMP2 are different from each other and the cost associated with the BMP3 is lower or greater than the sum of BMP1 and BMP2 costs, depending on the implementation area (see Figure 3). 


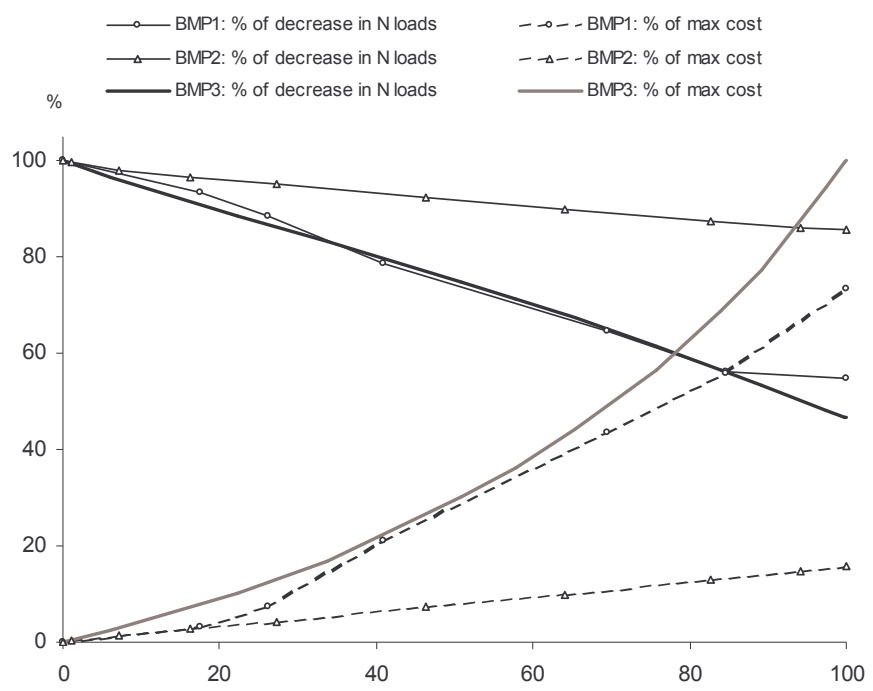

Figure 3: expected costs and effectiveness associated with 3 BMPs on the don watershed $(\mathrm{BMP} 3=\mathrm{BMP} 1+\mathrm{BMP} 2)$

\section{Step 6 : acceptability}

Unexpectedly, some farmers declared themselves ready to implement these BMPs, even if they are relatively costly. The same willingness to pay for environmental improvements on their own farms has been detected in some recent analysis (Dupraz et al. 2004).

Not all the farmers intend to consider the water quality. Indeed, farmers from types T1, T2, T5 and half of T8 do not intend to change their practices for environmental concerns in the next years. At the watershed scale, half of the agricultural area is cropped by farmers who do not foresee any modifications (see Figure 4). Farmers from T4 type do not intend to greatly modify their practices to improve the water quality, but they already have only small impact on it.

Farmers from types T3, T6 and half of T8 do intend to modify their practices within the next years : improvement of the non-organic fertilisation, better management of the organic fertilisers at the farm scale, and for some of them extensification of the forage area. 


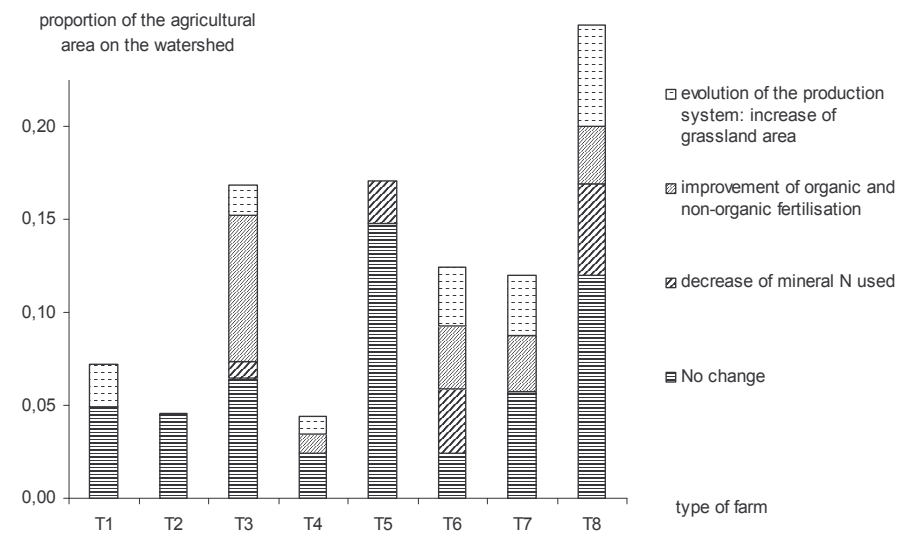

Figure 4: what do the farmers intend to modify within the next years on the Don watershed These modifications take place into farm trajectories: some farmers progressively adjust the fertilisers closer to the plants requirements (they crop $30 \%$ of the whole agricultural area on the Don watershed), others are engaged in a more important evolution of their farms, including important modifications of the cropping pattern (17\% of the whole agricultural area).

Diversity of the farms, willingness to pay for environmental improvements, farm evolution trajectories are key elements to deepen classical cost-effectiveness analysis.

\subsection{Crossbreeding between scientific results and on-farm implementation strategies}

The different simulations on the Don watershed suggest that the BMPs may have the expected effect on the water quality improvement only if they are implemented on a large share of the watershed area. Reaching water quality near the EU requirements of $25 \mathrm{mg}$ NO3/I would need a decrease of the average emissions from 15 to $20 \%$ on this watershed. This level can be reach while implementing BMP3 on more than $60 \%$ of the watershed.

Spontaneously, the farmers describe themselves as ready to implement modifications on 45 $\%$ and $35 \%$ of the agricultural area for BMPs 1 and 3 respectively. No local administration was ready to design an incentive scheme to improve the adoption rate, and thus, there was a need for a modification of the communication to the farmers. To encourage the farmers to adopt the BMPs, a strategy of advice has been differentiated according to the typology previously built. T3 farmers are open to practice modifications and assist easily to grouped advice sessions ; they have been proposed specific advice sessions dealing with spreading on grassland and composting techniques. The T6 farmers improved much than T5 group 
their research of savings and look for informations nowadays on work conditions, product quality, precision practices, production autonomy and reduction of the inputs. All these topics have been included in the advice and have been related to the possibilities of environmental improvement they allow.

Specific on-fields experiments and demonstration plots have been developed with the help of local cooperatives of farmers. These experiments focussed on the improvement of techniques and on their impact on the water quality. Lots of farmers attend these experiments, for various reasons: farmers from groups T7 looked for improvements of their techniques, but most of T5, T6 and T8 farmers participated. The key for participation seems to be the location of the experiments very close to the farm fields and having the same pedoclimatic conditions.

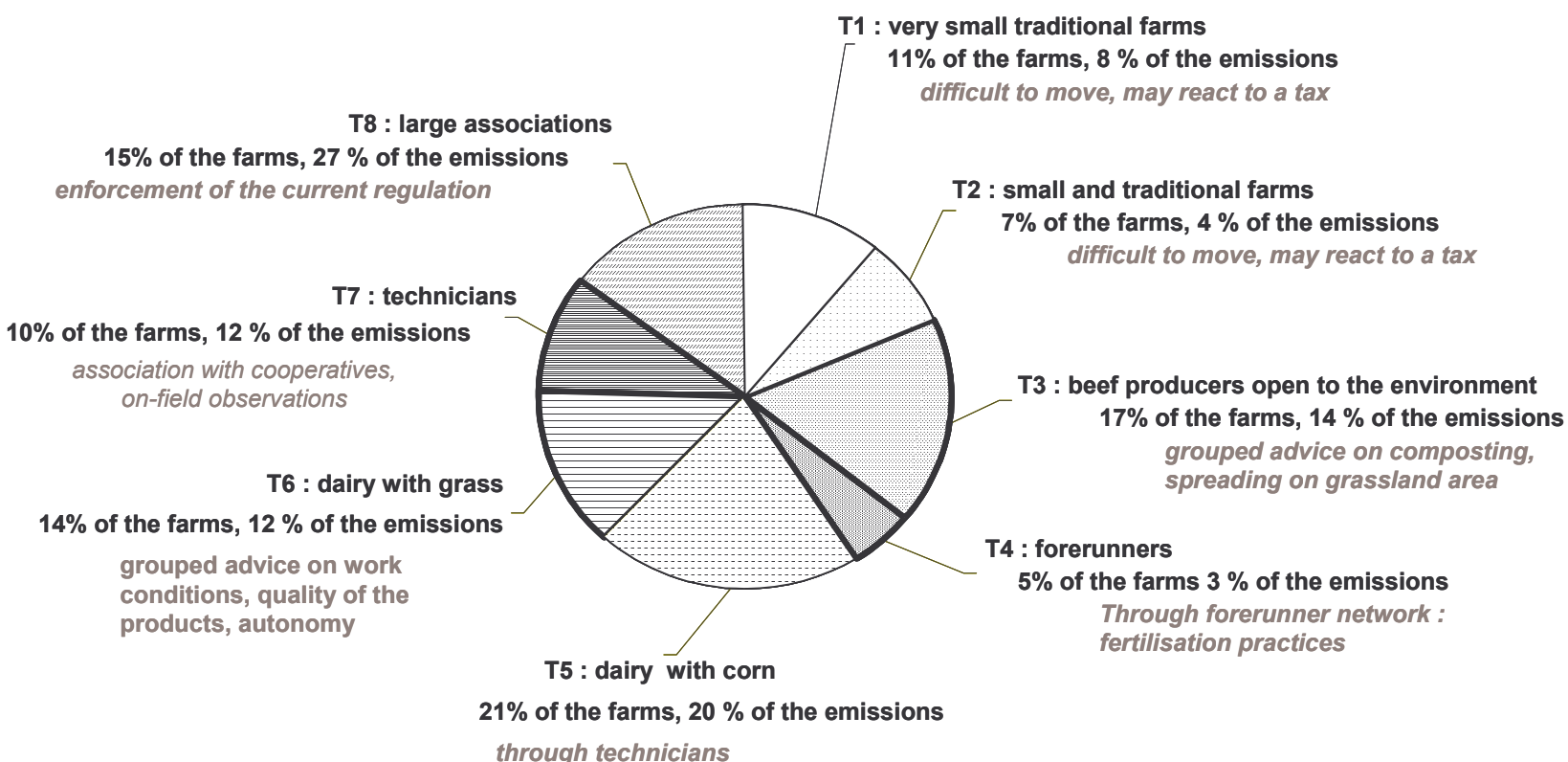

Figure 5: advice strategy designed to encourage the different farmers to implement BMPs on the Don watershed

\section{Conclusion}

Compensating farmers who adopt costly but pollution-decreasing practices is an idea that is supported by an increasing number of both farmers and environmentalists, and has already been tested in many areas in Europe. But stewardship compensation programs must overcome many difficulties, the most important being enforcements problems when the practices are not easily observed. In spite of these difficulties, EU Member States have to ensure a programme of measures to mitigate water pollution within the Water Framework 
Directive (2000/60/EC) and they need to select among the set of potential measures, the most cost-effective ones.

In this study, we compared several instruments designed to mitigate Non Point Source pollution on one given watershed. The different disciplinary glances focused simultaneously on BMPs allowed, while progressing in the agro-hydrological, economic and sociological fields, the development of an original integrated approach of assessment. This approach has been undertaken on three axis, the potential effectiveness of each instrument, the associated costs expressed as the variation of the farmers and the tax-payers' surplus, and the acceptability of the regulation assessed as the proportion of the farmers who benefit from this regulation, or who are ready to voluntary adopt it.

The design of policies to mitigate Non Point Source pollution from farms with a differentiated framework induces a better allocation of the abatement effort between farms: the empirical application on the Don watershed suggests that this abatement effort is mostly borne by the farms having the lower ratio profit/emissions, and, given this ratio, by the more efficient farmers. The cost investigation suggests that optimally differentiated regulations are the best way to conciliate effectiveness, implementation costs and acceptability of mitigating instruments.

Diversity of the farms, willingness to pay for environmental improvements, farm evolution trajectories are key elements to deepen classical cost-effectiveness analysis. Extending the consideration of farms diversity to design strategies of advice to encourage the farmers to adopt new practices is of utmost importance to improve the cooperation between different organisms (extension service, cooperatives, private sellers) and between the farmers.

The individual advice proposed to the farmers on the Don watershed satisfied the different consultants who intervene on the watershed. A similar approach is under development for the neighbouring watershed.

Many other improvements of this research can be foreseen: until now, we have only focussed on the potential effects and costs of particular BMPs. Obviously, the application of a specific BMP generates effects on other practices at the farm level. Developing a joint approach that incorporates the economical, sociological and physical aspects of the modelling through the building of a Decision Support System is in our opinion the key for future research in the area of mitigating Non Point source pollution from human activities. 
This would be the best way to help EU Member States to ensure a programme of measures to mitigate water pollution within the Water Framework Directive.

\section{References}

Anderson, D. L., and Flaig, E. G. (1995). "Agricultural best management practices and surface water improvement and management." Water Science and Technology, 31(8), 109-121.

Arnold J. G., Neitsch, S. L., Kiniry, J. R., and Williams, J. R., 2001, Soil and Water Assessment Tool - theoretical documentation. Grassland, soil and water research laboratory - ARS, Temple, Texas.

Bontems, P., Rotillon, G. and Turpin, N., 2004, Improvement of water quality as a joint production of milk when dairy farms are heterogeneous. In: EAAE (Ed.), 90th EAAE Seminar - Multifunctional agriculture, policies and markets: understanding the critical linkage. INRA-ESR, Rennes, pp. 7.

Bontems, P., Rotillon, G. and Turpin, N.,, 2005, Self-selecting agri-environmental policies with an application to the Don watershed, Environmental and Resource Economics, $31: 275-301$

Commission of the European Communities, 2005. Communication from the Commission to the Council and the European Parliament : 2004 Environemental Policy Review, Commission of the European Communities,, Brussels.

Deffontaines, J. P., Brossier, J., Benoit, M., Chia, E., Gras, F. et al., 1993, Agricultural practices and water quality : a research-development project, System studies in agriculture and rural developments. INRA, Paris, pp. 32-61.

Dellink, R., and van lerland, E., 2005, Pollution Abatement in the Netherlands: A Dynamic Applied General Equilibrium Assessment, Fondazione Eni Enrico Mattei, Working Papers: 2004.74.

DiLuzio, M., Srinivasan, R., Arnold, J. G., and Neitsch, S. L., 2002, ArcView Interface for SWAT2000 User's Manual. GSWRL Report 02-03, BRC Report 02-07, Texas Water Resources Institute TR-193y, College Station, TX.

Dupraz, P., Latouche, K. and Bonnieux, F., 2004, Economic implication of scale and threshold effects in agri-environmental processes, 90th EAAE Seminar: Multifunctional agriculture, policies and markets: understanding the critical linkage, Rennes. 
European Environment Agency, 2003. Europe's environment: the third assessment, European Environment Agency,, Copenhagen.

Gamborg, C. and Sandoe, P., 2005. Sustainability in farm animal breeding: a review. Livestock Production Science, 92(3), 221-231.

Harvey, D. R., 2004. Policy Dependency and Reform: Economic Gains versus Political Pains. Agricultural Economics, 31(2-3), 265-275.

Holmes P. R., 1996, Measuring success in water pollution control, Water Science and Technology, 34 (12)155-164.

Instance Nationale d'Evaluation du Contrat Territorial d'Exploitation, 2003. Le programme CTE, Rapport d'évaluation.

Kampas, A., and White, B., 2004, Administrative Costs and Instrument Choice for Stochastic Non-point Source Pollutants, Environmental and Resource Economics, 27(2), 109-133.

Lacroix, A., Beaudoin, N. and Makowski, D., 2005. Agricultural water nonpoint pollution control under uncertainty and climate variability. Ecological Economics, In Press, Corrected Proof.

Laplana, R., Turpin, N., Kaljonen, M., Strauss, P., Bärlund, I. et al., 2004. Guidelines to compare BMPs at watershed scale - Concepts, Methods, Demonstration, Implementation, FP5 AgriBMPWater project, Bordeaux.

Leparoux, P., Bégué, V. and Guilbert, E., 2001. Le Don : I'eau, la vie. Une opération FertiMieux pour l'amélioration de la qualité de l'eau par la modification des pratiques agricoles. Etat des lieux, bilan de 7 années de fonctionnement, perspectives., Chambre d'agriculture de Loire Atlantique, Nantes.

Morris, C., and Potter, C. (1995). "Recruiting the new conservationists: Farmers' adoption of agri-environmental schemes in the U.K." Journal of Rural Studies, 11(1), 51-63.

OECD, 2003, Voluntary Approaches for Environmental Policy, Effectiveness, Efficiency and Usage in Policy Mixes, Paris.

Pierce, M., 1998. Computer-based models in integrated environmental assessment, a report produced for the European Environment Agency, AEA Technology, Warrington.

Prato, T., 1999. Multiple Attribute Decision Analysis for Ecosystem Management. Ecological Economics, 30(2), 207-222.

Ruttan, V. W., 1996, What happened to Technology Adoption-Diffusion Research? Sociologia Ruralis Vol. 36, No. 1, pp. 51-73.

Turpin, N., Bontems, P., Rotillon, G., Barlund, I., Kaljonen, M., Tattari, S., Feichtinger, F., Strauss, P., Haverkamp, R., Garnier, M., Porto, A. L., Benigni G., Leone, A., Ripa M.N., Eklo O.M., Romstad E., Bordenave, P., Bioteau, T., Birgand, F., Laplana, R., Lescot, J.-M., Piet, L., and Zahm, F., 2005, AgriBMPWater: systems approach to environmentally acceptable farming, Environmental Modelling and Software, 20/2 (Policies and Tools for Sustainable 
Water Management in the European Union - Edited by R.A. Letcher and C. Giupponi), 187196.

Valentin, L., Bernardo, D. J., and Kastens, T. L. (2004). "Testing the Empirical Relationship between Best Management Practice Adoption and Farm Profitability." Review of Agricultural Economics, 26(4), 489-504.

Vatn, A., Bakken, L., Botterweg, P., and Romstad, E. (1999). "ECECMOD: an interdisciplinary modelling system for analyzing nutrient and soil losses from agriculture." Ecological Economics, 30(2), 189-205.

Ward, N. and Munton R. (1993). Conceptualizing Agriculture - Environment Relations. Combining Political Economy and Socio-Cultural Approaches to Pesticide Pollution. Sociologia Ruralis, 33, 127-145.

Webster, P., 1999. The Challenge of Sustainability at the Farm Level: Presidential Address. Journal of Agricultural Economics, 50(3), 371-387.

Wilson G.A. and Hart K., 2000, Farmer Participation in Agri-Environmental Schemes: Towards ConservationOriented Thinking? Sociologia Rauralis, 41,2, 254-274

Wu, J. J., and Babcock, B. A., 2001, Spatial heterogeneity and the choice of instruments to control nonpoint pollution, Environmental \& Resource Economics, 18(2), 173-192.

Wu, J. J., and Babcock, B. A., 1996, Contract design for the purchase of environmental goods from agriculture, American Journal of Agricultural Economics, 78(November 1996), 935-945.

Wu, J., 2004. Using Sciences to improve the economic efficiency of conservation policies. Agricultural and Resource Economics Review, 33(1), 18-23. 


\section{Working Papers INRA - Unité ESR Rennes}

05-01 Effets de seuils et coordination des efforts agri-environnementaux, Dupraz P., Latouche K., Turpin N.

04-02 Designing policies for the supply of non-commodity outputs under farms' heterogeneity, Bontems P., Rotillon G., Turpin N.

04-01 Investement and financial constraints of Polish farmers. Latruffe L.

03-10 Technical efficiency and farm financial management in countries in transition. Davidova S., Latruffe L.

03-09 La réforme de la PAC de 2003, le principe du découplage des aides directes et la régionalisation : Quels impacts sur le secteur européen de la pomme de terre ? Gohin A.

03-08 Farm credit and investment in Poland : A case study. Latruffe L.

03-07 Une politique agricole commune au service de l'emploi ? Analyse économique du modèle de l'agriculture paysanne de la Confédération paysanne. Gohin A., Guyomard H.

03-06 The phasing out of EU agricultural export subsidies:Impacts of two management schemes. Gohin A., Gautier P.

03-05 The Fischler's Proposals for the Common Agricultural Policy: Paving the Way for the Future? Guyomard H., Le Bris K.

03-04 Mesures agro-environnementales et demande de travail agricole. Dupraz P.

03-03 The Specification of Price and Income Elasticities in Computable General Equilibrium Models: An application of Latent Separability Gohin A.

03-02 Les exploitations agricoles polonaises à la veille de l'élargissement : structure économique et financière Latruffe $L$.

03-01 La mesure du pouvoir de vote Chantreuil F., Andjiga N-G., Lepelley D. 
02-06 Technical and scale efficiency of crop and livestock farms in Poland : Does specialisation matter ? Latruffe L., Balcombe K., Davidova S., Zawalinska K

02-05 Determinants of technical efficiency of crop and livestock farms in Poland Latruffe L., Balcombe K., Davidova S., Zawalinska K.

02-04 The new banana import regime in the european union : A quantitative assessment Guyomard H., Le Mouël C.

02-03 Farm credit rationing and government intervention in Poland Latruffe L., Fraser R.

02-02 Reducing farm credit rationing : An assessment of the relative effectiveness of two government intervention schemes Latruffe L., Fraser R.

02-01 Tariff protection elimination and Common Agricultural Policy reform : Implications of changes in methods of import demand modelling. Gohin A., Guyomard H., Le Mouël C. 